\title{
Pro-Kontra Gibah dalam Tinjauan Hadis dan Konteks Maraknya Perilaku Gosip
}

\author{
Muhammad Luthfi Dhulkifli \\ UIN Sunan Kalijaga Yogyakarta \\ luthfidhulkifli@gmail.com
}

DOI: $10.29240 /$ alquds.v3i1.681

Submitted: 2019-01-14| Revised: 2019-03-07 |Accepted: 2019-04-30

\begin{abstract}
This paper addressed to cover both sides in case of gibah or gossip. It is important due to the fact that people often talk about others by their negativity. This paper focuses on Muslim hadith number 2589 as multi-interpreted hadith by its syarah (interpretation) that gives a proportion of both legal and prohibited. This paper tries to find in three points: quality of Muslim 2589 hadith, syarah, and the contextualization of hadith. To answer these questions, this research work on Yusuf Qaradhawi's perspective i.e corresponding to the Qur'an; collecting other hadiths; linguistic analyzing; and contextualizing. In the end, Muslim 2589 hadith is a shahih hadith which is possible to do further research by its matan and the meaning. Although gibah is categorized as prohibited, there are several cases that make it legal such as asking for help or asking for fatwa and advice. Gibah or gossip should be abandoned regarding its negativity not only for others but also themselves.
\end{abstract}

Keywords: Gibah; Gossip; Hadith

\begin{abstract}
Abstrak. Tulisan ini akan memberikan penjabaran terkait sisi pro dan kontra perbuatan gibah atau gosip. Ini menjadi penting karena di masa kini, membicarakan keburukan sesama manusia sudah menjadi pemandangan yang biasa. Fokus penelitian adalah hadis riwayat Muslim nomor 2589 yang dianggap multi tafsir karena mengandung pembolehan maupun pelarangan gibah. Tulisan ini akan menelisik lebih jauh dari tiga hal meliputi: kualitas keshahihan hadis Muslim 2589, syarah hadis, dan kontekstualisasi atas matan hadis tersebut. Untuk menjawab hal ini, penulis mengacu pada pemikiran hadis Yusuf Qaradhawi yang meliputi: konfirmasi dengan al-Qur'an; pengumpulan hadis-hadis terkait; analisa kebahasan; dan kontekstualisasi. Pada akhirnya, hadis Muslim 2589 berkualitas shahih sehingga dapat dikaji lebih dalam dari sisi matan dan pemaknaannya. Meskipun hukum dasar gibah adalah haram, namun ada beberapa pengecualian yang memperbolehkannya semisal meminta pertolongan ataupun meminta fatwa dan nasihat. Perilaku gibah / gosip sebaiknya dihindari karena berpotensi merugikan orang lain dan juga diri sendiri.
\end{abstract}

Kata kunci: Gibah ; Gosip; Hadis 
54 | AL QUDS : Jurnal Studi Alquran dan Hadis vol. 3, no 1, 2019

\section{Pendahuluan}

Setiap manusia dituntut untuk berbaik sangka terhadap sesamanya dengan tidak membicarakan keburukannya pada orang lain. Namun, kenyataan yang ada menunjukkan hal sebaliknya lantaran sering dijumpai seseorang yang membicarakan keburukan orang lain baik secara terang-terangan maupun tersembunyi. Perbuatan semacam ini lazim disebut sebagai gosip atau gibah. Gosip atau gibah terhadap sesama akan memberikan dampak yang sangat buruk dalam jalinan kemitraan antar manusia. Lebih jauh lagi, perbuatan ini akan berakibat pada permusuhan terhadap pihak yang bersangkutan.

Terkait bahanya permusuhan antar sesama manusia, nabi Muhammad menjelaskan bahwa lidah manusia merupakan salah satu sumber utama munculnya dusta, buruk sangka, adu domba, bertengkar, bermusuhan, mengutuk, bersenda-gurau yang berlebihan, menghina, berdebat kusir, serta gibah (menggunjing). ${ }^{1}$ Gibah dapat melukai hati seseorang, menimbulkan permusuhan, mengacaukan hubungan kemasyarakatan, dan memunculkan rasa saling curiga. Berbagai potensi dampak ini kemudian mendorong Majelis Ulama Indonesia mengeluarkan fatwa terkait gosip atau gibah di media sosial. ${ }^{2}$

Adanya fatwa dari lembaga Majelis Ulama Indonesia tidak lantas menghentikan perilaku masyarakat dalam bergosip baik melalui media sosial maupun secara langsung. Membicarakan keburukan sesama manusia seolah telah menjadi sebuah kewajaran di masa kini dengan adanya tayangan-tayangan yang menyajikan acara gosip. ${ }^{3}$ Gosip tentang public figure seperti artis, tokoh politik, dan sebagainya selalu mengundang antusias publik untuk terus mengikuti perkembangannya. Antusias masyarakat dalam mengikuti perkembangan gosip menjadikan para produser TV terus menyajikan tayangan-tayangan berbau gosip tanpa disertai edukasi yang cukup.

Gosip sangaat erat kaitannya dengan konteks gibah dan telah disinggung dalam hadis nabi. Terdapat sebuah hadis yang masih menimbulkan pro-kontra hingga dalam pensyarahannya terkait perbuatan gibah. Adapun hadis tersebut adalah:

${ }^{1}$ Hadis :

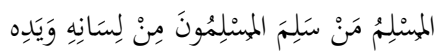

"Orang Islam sejati adalah orang Islam yang mampu menjadikan orang lain aman dari lidah dan tangannya" Imam Bukhari, Shabih Al-Bukhari (Riyadh: Dar 'Alam al-Kutub, 1996), 1, 13.

${ }^{2}$ Selengkapnya lihat di Fatwa Majelis Ulama Indonesia Nomor 24 Tahun 2017, Komisi Fatwa Majelis Ulama Indonesia, hlm. 1-20.

${ }^{3}$ Muhammad Munzir, "Gosip Dalam Pandangan Hadis: Suatu Kajian Tematik” (Fakultas Ushuluddin UIN Alauddin, 2011), 25.. 


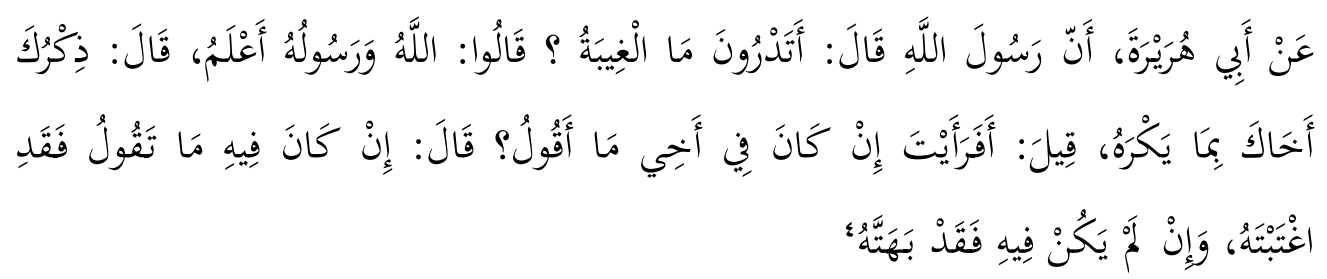

Dibutuhkan sikap kritis untuk menghadapi pemaknaan hadis-hadis nabi karena dalam sejarahnya hadis telah mengalami transmisi dari sebuah realita menuju ke dalam teks hadis. ${ }^{5}$ Ditambah lagi, hadis tersebut tidak secara tegas menyebut kebolehan ataupun keharaman melakukan perbuatan gibah. Baik gosip ataupun gibah terkesan memiliki banyak sisi negatif dengan berbagai dampak yang ditimbulkan. Meskipun demikian, terdapat beberapa jenis gibah yang diperbolehkan dalam pemaknaan hadis terkait gibah ini.

Posisi hadis sebagai sumber penting umat Islam menjadi titik pijak yang penting dalam memaknai gibah. Terdapat banyak hadis yang memuat konteks terkait gibah, akan tetapi belum banyak mendapat perhatian. Beberapa kajian yang penulis temukan terkait gibah masih ditinjau dari sudut pandang lain semisal: dampak buruk gibah terhadap kesehatan manusia oleh Nelly Azizah ${ }^{6}$ dan penelitian kualitatif oleh Eyal Eckhaus bersama Batia Ben-Hardor ${ }^{7}$ terkait baik buruk dampak gosip dalam sebuah pertemanan. Di sisi lain, meskipun telah terdapat sejumlah kajian gibah dalam perspektif hadis oleh Musyfikah Ilyas ${ }^{8}$

${ }^{4}$ Artinya: Dari Abu Hurairah bahwa Rasulullah Shallallahu 'alaihi wassallam pernah bertanya "Tahukah kalian apa itu gibah?" Mereka menjawab, "Allah dan Rasul-Nya yang lebih tahu." Beliau bersabda, "Yaitu engkau menceritakan tentang saudaramu apa yang tidak ia suka."Lalu ditanyakan kepada beliau, "Lalu bagaimana jika pada diri saudaraku itu kenyataannya sebagaimana yang saya ungkapkan?"Maka beliau bersabda, "Apabila cerita yang engkau katakan itu sesuai dengan kenyataan maka engkau telah meng-gibah inya.Dan apabila ternyata tidak sesuai dengan kenyataan dirinya maka engkau telah berdusta atas namanya (fitnah)." Muslim ibn Hujjaj Al-Qusyri Al-Naisabury, Shabih Muslim (Beirut: Dar Ihya' al-Kutub al-'Arabiyah, n.d.), 4, 2001.

${ }^{5}$ Nurun Najwah, Ilmu Ma'anil Hadis, Metode Pemahaman Hadis Nabi: Teori Dan Aplikasi (Yogyakarta: Penerbit Cahaya Pustaka, 2008), 2.

${ }^{6}$ Azizah Nelly, "Kajian Buruk Sangka Dan Gibah Bagi Kesehatan Tubuh Manusia (Telaah Konsep Getaran Dan Gelombang)" (Proseding Seminar Nasional Pendidikan Fisika, FITK UNSIQ, February 2018), 144-51.

${ }^{7}$ Eyal Eckhaus and Batia Ben Hador, "To Gossip or Not to Gossip: Reactions to a Perceived Request to Gossip - A Qualitative Study," Trames. Journal of the Humanities and Social Sciences 22 (September 20, 2018): 273, doi:10.3176/tr.2018.3.04.

${ }^{8}$ Musyfikah Ilyas, "Ghibah Perspektif Sunnah," Jurnal Al-Qadau: Peradilan Dan Hukum Keluarga Islam 5, no. 1 (July 3, 2018): 141-59, doi:10.24252/al-qadau.v5i1.5677. 
pada tahun 2018 lalu dan Muhammad Munzir ${ }^{9}$ dalam skripsinya mengenai kajian tematik atas hadis hadis gibah pada 2011, tulisan tersebut masih mengarah pada larangan dan dampak negatif gibah. Maka dari itu, tulisan ini akan memberikan pandangan yang berimbang terkait larangan maupun pembolehan gibah dalam konteks saat ini.

Secara keseluruhan, tulisan ini diarahkan untuk menjawab pertanyaanpertanyaan mendasar tentang gibah dalam perspektif hadis. Hadis yang dijadikan sebagai pijakan utama adalah hadis nomor 2589 riwayat Muslim. Melalui hadis tersebut, analisis akan dilakukan mulai dari, pertama, sisi keshahihan hadis untuk menentukan kelayakan hadis tersebut sebagai hujjah atas perbuatan gibah. Kedua, penjabaran atas syarah hadis Muslim 2589 melalui kerangka berpikir dari Yusuf Qardhawi, yakni konfirmasi terhadap ayat al-Qur'an; konfirmasi dengan hadis terkait; dan analisis kebahasaan. Terakhir, pemaknaan kontekstual atas hadis Muslim nomor 2589 terkait pro dan kontra perbuatan gibah dan hubungannya dengan gosip.

\section{Takhrij Hadis Tentang Gibah}

Hadis Muslim nomor 2589 menjadi referensi utama dalam pembahasan ini. Hadis ini dipandang tepat karena dapat dianalisis dengan dua sisi yang berbeda yaitu pro dan kontra terhadap gibah, sehingga antara yang pro dan kontra dapat menggunakan hadis tersebut sebagai hadis utama. Jika dibandingkan dengan hadis yang lain, hadis ini bisa mendefinisikan maksud dari gibah itu sendiri, sehingga dapat dipahami apa itu gibah . Hadis-hadis lain yang sejenis hanya memaparkan akibat yang diperoleh jika orang melakukan gibah .

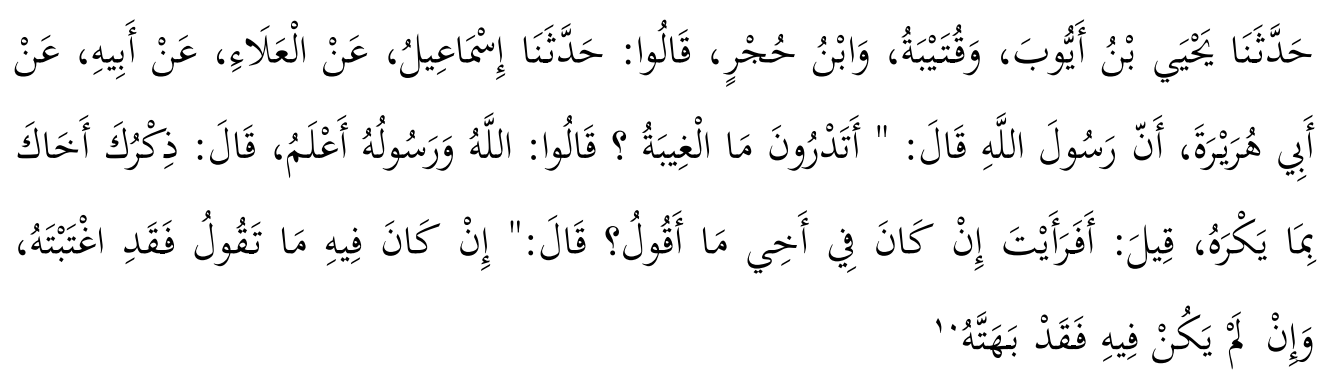

Telah menceritakan kepada kami Yabya bin Ayyub dan Qutaibah dan Ibnu Hujr mereka berkata; telab menceritakan kepada kami Isma'il dari Al A'laa dari Ayabnya dari Abu Hurairah babwa Rasulullah pernah bertanya "Tabukah kalian apa itu gibah ?" Mereka menjawab, "Allah dan Rasul-Nya yang lebib tabu." Beliau bersabda, "Yaitu engkau menceritakan tentang saudaramu apa yang tidak dia suka."Lalu ditanyakan kepada beliau,

\footnotetext{
9 Munzir, "Gosip Dalam Pandangan Hadis: Suatu Kajian Tematik," $132 .$.

${ }^{10}$ Al-Naisabury, Shabih Muslim, 4, 2001..
} 
"Lalu bagaimana jïka pada diri saudaraku tersebut memang sebagaimana apa yang saya ungkapkan?"Maka beliau bersabda, "Apabila cerita yang engkau katakan itu sesuai dengan kenyataan maka engkau telah meng-gibah nya. Dan apabila ternyata tidak sesuai dengan kenyataan dirinya maka engkau telah berdusta atas namanya (fitnab)." (HR. Muslim)

Setelah dilakukan takhrij melalui pencarian hadis yang serupa, ditemukan beberapa hadis yang terdapat dalam kutub al-Tis'ah. Hadis-hadis tersebut memiliki beragam jalur periwayatan dan memiliki redaksi yang serupa. Diantara hadis tersebut adalah ${ }^{11}$ : HR Abu daud nomor $4874^{12}$ HR Tirmidzi nomor $1934^{13}$ HR Ad-Darimi nomor $2756^{14}$.

\section{Kritik Sanad Hadis Gibah Dalam Riwayat Muslim}

Untuk melihat keshahihan sebuah hadis, hal paling pertama yang harus dilihat adalah sanad. Apabila sanad sebuah hadis telah dinyatakan shahih, barulah matan hadisnya bisa dilakukan sebuah penelitian. Matan hadis akan dipandang tidak shahih apabila sudah ditemukan cacat dalam sanadnya. Berikut ini akan disajikan skema sanad perawi guna diteliti lebih lanjut terkait kualitas dari masing-masing perawi hadis tentang gibah ini. Adapun skema sanad perawi hadis tersebut adalah:

(Rasulullah SAW. $\rightarrow$ Abu Hurairah $\rightarrow$ Abdurrahman bin Ya'kub $\rightarrow$ Al-Alaa' $\rightarrow$ Ismail $\rightarrow$ Ibnu Hujr, Qutaibah, dan Yahya bin Ayyub $\rightarrow$ Imam Muslim)

\section{Penilaian perawi hadis}

Pengujian terhadap para perawi hadis dikenal dengan kajian jarh wa atta'dil. ${ }^{15}$ Kajian ini sangat penting untuk dapat membedakan hadis yang shahih

${ }^{11}$ Penomoran hadis yang dicantumkan merujuk pada aplikasi Lidwa Mausu'ah. Hal ini dimaksudkan agar memudahkan pembaca untuk melihat hadis beserta terjemahannya.

12 Imam Abu Dawud, Sunan Abu Dawnd (Beirut: Maktab ad-Dirasat wa al-Buhuts fi Dar al-Fikr, n.d.), 4, 269.

${ }^{13} \mathrm{Abu}$ 'Isa Muhammad ibn 'Isa ibn Saurah al-Turmudzi, Sunan At-Turmudzi (Beirut: Dar al-Fikr, 1994), 3, 393.

14 Abdullah ibn Abdul Rahman ad-Darimi, Sunan Ad-Darimi (Saudi Arabia: Dar alMughni li an-Nashr wa al-Tauzi', 2000), 3. 1782.

${ }^{15} \mathrm{Jarh}$ wa al-Ta'dil merupakan salah satu ranah kajian sanad hadis yang membahas tentang penilaian terhadap kualitas kepribadian seorang perawi hadis dari Imam lain. Tidak jarang ditemukan penilaian dari ulama' yang menilai dengan kualitas buruk sesuai dengan kepribadiannya. Lihat Muhammad 'Ajaj al-Khathib, Ushul Al-Hadis: Ulumubu Wa Musthala'ubu (Beirut: Dar al-Fikr, 2011), 168. 
dengan hadis yang cacat dan hadis yang dapat diterima ataupun ditolak. ${ }^{16}$ Berikut ini akan dicantumkan biografi singkat para perawi hadis yang mencukupi untuk dilakukan kajian jarb wa at-ta'dil:

\section{Abu Hurairah}

Abu Hurairah berasal dari kalangan sahabat. Nama lengkapnya adalah Abdurrahman bin Shakhr, sedangkan nama kuniyahnya adalah Abu Hurairah. ${ }^{17}$ Abu Hurairah dikenal dengan sebutan Abu al-Syam dan bergelar Abu Aswad. Gelar tersebut diberikan oleh nabi Muhammad pada tahun $7 \mathrm{H} / 629 \mathrm{M}$. Disebutkan bahwa hadis yang diriwayatkan melalui jalur Abu Hurairah sebanyak 5374 hadis dengan lebih dari 800 perawi yang menerima hadis darinya. ${ }^{18}$

Abu Hurairah meriwayatkan hadis dari Nabi Muhammad SAW, Salman Al-Farisi, Zaid bin Tsabit, dan lain-lain. Murid-muridnya antara lain: Muslim bin Abdullah, Sulaiman bin Yasar Al-Hilali, Abu Tamim Az-Zuhri, Said bin Al Musayyab, Abu Ja'far Al-Anshari, dan lain-lain. Mengenai kualitasnya, jumhur ulama berpendapat bahwa semua rawi yang berasal dari kalangan sahabat adalah adil. Abu Hurairah wafat pada tahun 57 H. Imam Syafi'i menyatakan bahwa Abu Hurairah adalah orang yang paling banyak menghafal hadis di masanya.

\section{Abuhu (Ayahnya dari Al-Alaa')}

Nama Lengkap beliau adalah Abdurrahman ibn Ya'qub Al Juhaniy Al Madani dan tergolong dalam tabi'in kalangan pertengahan. Beliau banyak menghabiskan masa hidupnya di Madinah. Diantara guru-gurunya adalah: $\underline{A b u}$ Hurairah, Abdurrahman ibn Yamin al Madani, Abdullah ibn Abbas, Abdullah ibn Umar ibn Khattab, Abdul Malik ibn Naufal ibn Al Haris. Beliau juga memiliki sejumlah murid dalam kajian hadis, diantaranya: Anaknya (Al Alaa ibn Abdurrahman ibn Ya'qub), Salim Abu An Nadhr, Umar ibn Hafs ibn Dzakwan. Mengenai penilaian terhadap beliau, Ibnu Hibban menganggapnya sebagai seorang yang Tsiqqoh, Al-Ijli juga menyatakan Tsiqqoh, dan Imam an-Nasa'i menyebut tidak ada cacat..$^{19}$

\section{Al-Alaa'}

Nama lengkapnya adalah Al-Alaa' ibn Abdurrahman Al Hiraqiy. Al-Alaa' wafat pada tahun $130 \mathrm{H}$. Nama kuniyahnya adalah Abu Syubul dan tinggal di Madinah. Guru-guru beliau dalam mendapatkan hadis diantaranya: Ibnu umar,

16 Ibid.

${ }_{17}$ Syihab al-Din Abu al-Fadhl Ahmad ibn Hajar al-'Asqalani, Tahzib Al-Tahzib (Beirut: alTuras al-'Arabi, 1993), 4, 66.

18 TM Hasbi as-Shiddieqi, Sejarah Pengantar Ilmu Hadis (Semarang: Pustaka Rizki Putera, 1999), 254-55.

19 Yusuf bin Abdurrahman Yusuf, Tahdzibul Kamal Fi Al-Asma' Al-Rijal (Beirut: Muassasah al-Risalah, 1980), 18. 18. 
Anas, Abbas ibn Sahl ibn Sa'd, Ayahnya (Abdurrahman bin Ya'kub), Ali ibn Majidah Nuaim Al Mujmir, Sa'd ibn Ka'ab ibn Malik. Adapun murid-murid yang belajar secara langsung meliputi: Ismail ibn Ja'far ibn Abi Katsir, Muhammad ibn Ajlan, Anaknya (Syibli), Ibn Ishaq, Ibnu Juraij, Ubaidillah ibn Umar, Hafsh ibn Maysarah. Mengenai al-Alaa', Abdullah ibn Ahmad menilai sebagai Tsiqqoh, tidak pernah mendengar tentang keburukannya, Hal demikian juga diungkapkan oleh Abu Hatim dengan menyebut sebagai Shalih, Tsiqqoh, Ibnu Hibban mengatakan Tsiqqoh, begitu pula dengan Ibnu Said dan Tirmidzi. ${ }^{20}$

\section{Ismail.}

Nama lengkapnya adalah Ismail ibn Ja'far ibn Abi Katsir Al Anshari. Beliau wafatpada $180 \mathrm{H}$ dan nama kuniyahnya adalah Abu Ishaq. Para guru Ismail yang dikenal meliputi: Al-Alaa' ibn Abdurrahman ibn Ya'qub, Hubaib ibn Hassan ibn Abi Al Asyras, Daud ibn Qhais Al Farra', Rabiah ibn Abdul Rahman, Malik ibn Anas, Humaid At Thawil, Muhammad ibn Abi Al Harmalah. Selama masa hidupnya, Ismail juga menyebarkan keilmuannya kepada muridmuridnya yang diantaranya: Ali ibn Hujr As Sa'diy Al Marwazi, Qutaibah ibn

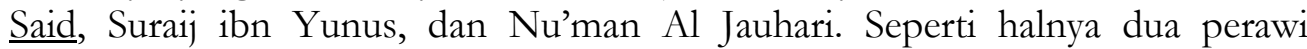
sebelumnya, menurut Ahmad, Abu Zuráh, Ibnu Muayyan, Ibnu Said dan anNasai menilai Ismail sebagai sosok yang Tsiqqob. ${ }^{21}$

\section{Ibn Hujr.}

Nama Lengkapnya Ali ibn Hujr ibn Iyas ibn Maqathil ibn Mukhadisy As-Sa'diy. Beliau dilahirkan pada $154 \mathrm{H}$ dan memiliki masa hidup hampir 100 tahun saat wafat $253 \mathrm{H}$. Nama kuniyahnya adalah Abu Al Hasan dan beliau banyak menghabiskan masa hidupnya di Baghdad. Para ulama' tempatnya belajar hadis adalah: Ismail ibn Ja'far, Ismail ibn Ulayyah, Ishak ibn Najih, Al Malati, Ismail ibn Ayasi. Beliau juga memunculkan murid-murid yang kemudian sangat mashur dalam bidang hadis semisal: Bukhari, Muslim, Tirmidzi, Nasai, Ahmad ibn Muslim Al Abbari Al Baghdadi, Abu Ishak Ibrahim ibn Ismail Al Ambary. Abu Ali Muhammad ibn Ali ibn Hamzah Al Marwazi memuji beliau sebagai Fadhi, Hafidr, an-Nasai menyebutnya sebagai Tsiqqoh, Ma'mun, Hafid, Shoduq, sementara Abu Bakar Al-Khatib mengatakan Shodu, Hafiď, Mutqan/diyakini keshalihannya. ${ }^{22}$

\footnotetext{
${ }^{20}$ Ibid., 22. 520.

${ }^{21}$ Ibid., 3. 56.

22 Ibid., 20. 355.
} 


\section{Qutaibah}

Nama lengkap dari Qutaibah adalah Qutaibah ibn Said. Beliau lahir pada $148 \mathrm{H}$ dan wafat $240 \mathrm{H}$. Nama kuniyahnya adalah Abu Raja'. Diantara gurugurunya: Ismail ibn Ja'far, Ismail ibn Ulayyah, Ibrahim ibn Said Al-Madani, Ismail ibn Abi Awyus, Abi Dhomiroh, Anas ibn Iyyadh, Abu Ayub ibn Jabir. Diantara para ulama' yang belajar kepada Qutaibah adalah: Yahya Ibrahim ibn Ishaq, Ahmad ibn Hanbal, Ahmad ibn Said Ad-Darimi, Ahmad ibn Sayar AlMaruzi, Ahmad ibn Abdurrahman, Abu Hamid Ahmad ibn Qudamah ibn Muhammad ibn Abdillah. Adapun mengenai kualitas pribadinya, menurut Abu Bakar Al-Asram: Pujian atasnya, Ahmad ibn Abi Haistam dari Yahya ibn Ma'in dan Abu Hatim dan Nasa'i menyatakan Tsiqqoh, an-Nasa'i dan Ibn Kharas menyebut sebagai Shoduq/jujur. ${ }^{23}$

\section{Yahya ibn Ayub}

Beliau memiliki nama lengkap Yahya ibn Ayub Al-Maqabiry. Beliau dilahirkan pada $157 \mathrm{H}$ dan wafat pada $233 \mathrm{H}$. Nama kuniyahnya Abu Zakariya'. Para guru yang mengajarkan hadis padanya mencakup: Ismail ibn Ibrahim ibn Sulaiman al-Muaddab, Ismail ibn Ja'far al-Madani, Ismail ibn Ulayyah, Hasan ibn Karmani, Hamid ibn Abdurrahman, Ismail bin Ja'far. Sementara murid-murid yang belajar kepadanya meliputi: Muslim, Ahmad ibn Hasan ibn Abdul Jabar Ash-Shufi, Abu Daud, Ahmad ibn Hanbal, Abu Bakar Ahmad ibn Ali ibn Said al-Qhadi, Ahmad ibn Ali. Dikatakan oleh Ibnu Qoni jika beliau adalah Tsiqqoh, Al-Husain ibn Muhammad ibn Al-Fahm menyebut Wara'/ lebih mengutamakan urusan akhirat, Tsiqqoh, Abu Hasan Al-Maymun menilainya Sholib/jujur begitu pula Ali Ibn Al-Madini dan Abu Hatim, Abu Syuaib Al Haron memuji dengan julukan Hamba Piliban Allah, terakhir Musa ibn Harun ibn Abdillah Sarij ibn Yunus menganggapnya sebagai Sholih. ${ }^{24}$

\section{Imam Muslim}

Imam Muslim memiliki nama asli Muslim al-Hajjaj al-Qusyairi alNaisaburi. Beliau lahir dan wafat di kota Naisabur pada tahun 204 H dan 261 H. Meskipun hanya memiliki usia yang tidak terlalu panjang, Imam Muslim menunjukkan bahwa dirinya memang sosok yang penting dalam kajian hadis. Daya hafalnya yang tinggi membuatnya mampu mengarang sebuah kitab yang masih sangat penting hingga saat ini. Sepanjang hidupnya, Imam Musli telah belajar dengan banyak guru sperti: Yahya bin Ayyub, Qutaibah, Ibnu Hujr, Shaq bin Rohawayh, Muhammad bin 'Amr, dan Bukhari. Tidak hanya itu, Imam Muslim juga memiliki sejumlah murid-murid seperti: Yahya bin Sha'id,

\footnotetext{
${ }^{23}$ Ibid., 23. 523.

${ }^{24}$ Ibid., 31, 238.
} 
Muhammad bin Makhlad, Muhammad bin Ishaq bin Khuzaimah, Muhammad bin Abdul wahhab al-Farro'. ${ }^{25}$

Dari kajian kritik sanad yang telah penulis cermati, penulis berkesimpulan bahwa sanad hadis tentang gibah tersebut memenuhi syarat keshahihan sanad. Hal ini dikarenakan seluruh syarat keshahihan sebuah sanad telah terpenuhi. Syarat-syarat keshahihan sanad hadis gibah tersebut ditunjukkan melalui ketersambungan sanad (ittishal al-sanad) dengan adanya jalur runtut antar perawi dari generasi ke generasi melalui hubungan sebagai guru dan murid; para perawinya kredibel (tsiqqahu al-ruwah) yang terlihat dari penilaian yang positif terhadap seluruh perawi tanpa ada yang menilai sebagai sosok yang cacat; serta terakhir adalah intelektualitas perawi (dhabtu al-ruwab) melalui kemampuan mereka dalam mengingat hadis.

\section{Kritik Matan Hadis Tentang Gibah}

Analisa terhadap matan hadis dilakukan dalam kerangka pemikiran hadis Yusuf Qaradhawi yang penulis sederhanakan dalam beberapa tahap berikut:

\section{Konfirmasi dengan al-Qur'an}

Untuk memahami hadis dengan benar, jauh dari penyimpangan dan salah menta'wilkan harus dilakukan di bawah naungan al-Qur'an dalam lingkup orientasi Rabbani yang benar dan adil. Adapun hadis berfungsi sebagai penjelasan teoritis dan implementasi praktis terhadap al-Qur'an. ${ }^{26}$ Dalam kaitannya dengan perbuatan gibah, al-Qur'an menjelaskan:

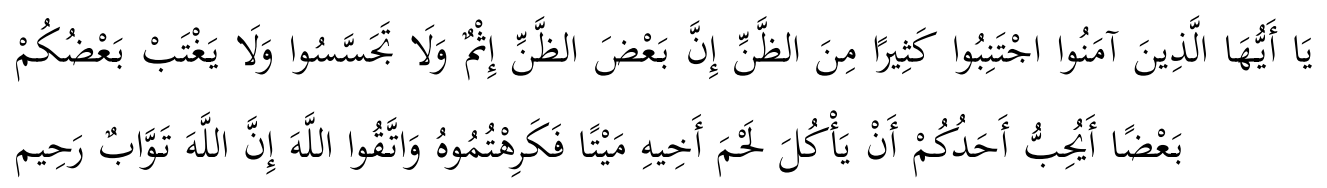

"Hai orang-orang yang beriman, jaubilab kebanyakan purba-sangka (kecurigaan), karena sebagian dari purba-sangka itu dosa. Dan janganlah mencari-cari keburukan orang dan janganlah menggunjingkan satu sama lain. Adakah seorang diantara kamu yang suka memakan daging saudaranya yang sudah mati? Maka tentulah kamu merasa jijik kepadanya. Dan bertakwalah kepada Allah. Sesunggubnya Allab Maba Penerima Taubat lagi Maba Penyayang”. (QS.Al-Hujurat: 12)

${ }^{25}$ Keterangan bergaris bawah menunjukkan adanya keterkaitan hubungan antar satu perawi dengan perawi lainnya sebagai guru dan murid.

${ }^{26}$ Suryadi, "Metode Pemahaman Hadis Nabi (Telaah Atas Pemikiran Muhammad AlGhazali Dan Yusuf Al-Qardhawi)" (Program Pascasarjana UIN Sunan Kalijaga, 2004), 148-49. 
Menggunjing adalah membicarakan aib dan keburukan seseorang sedangkan yang dibicarakan tidak hadir. Sesorang yang menggunjingkan yang lainnya sama dengan memakan daging manusia yang telah mati (bangkai). Perumpamaan yang diberikan al-Qur'an memang menunjukkan perintah untuk menghindari perbuatan gibah . Namun, mengungkapkan kesalahan atau kejelekannya dihadapannya (orang yang berperangai buruk) secara langsung dapat menjadikannya memperbaiki kesalahan dan kejelekan tersebut. ${ }^{27} \mathrm{Hal}$ ini setidaknya mengindikasikan bahwa tidak semua hal tentang pembicaraan buruk seseorang itu terlarang atau tidak diperbolehkan.

\section{Konfirmasi dengan hadis terkait}

Dalam rangka mencari makna hadis yang sesungguhnya, teks-teks hadis tidak dapat dipahami sebagai teks yang berdiri sendirian, akan tetapi harus dipahami sebagai sebuah kesatuan dengan tema tertentu yang terkait. Dengan cara tersebut, makna yang dihasilkan lebih komprehensif dan penafsiran suatu hadis dapat dimengerti maksudnya dengan lebih jelas dan tidak menimbulkan pertentangan antara hadis satu dengan yang lainnya. ${ }^{28}$ Adapun beberapa hadis yang terkait dengan gibah adalah:

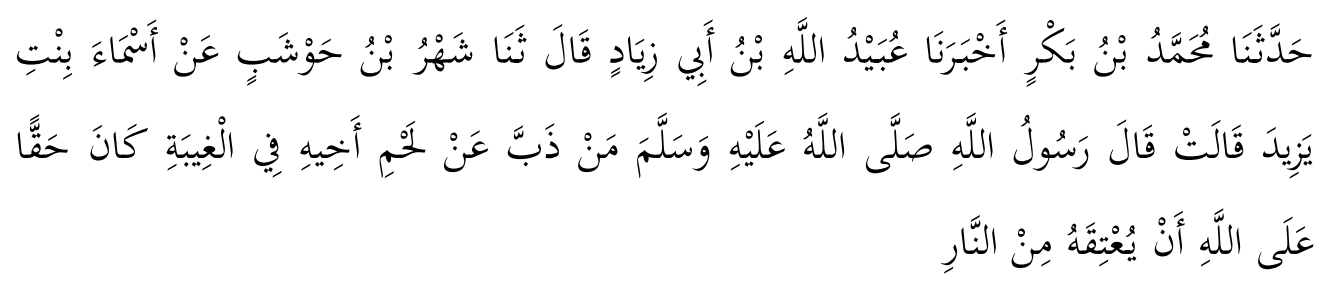

Telah menceritakan kepada kami Muhammad bin Bakr telah mengabarkan kepada kami Ubaidullab bin Abu Ziyad dari Syabr bin Hausyab dari Asma' binti Yazid dia berkata, "Rasulullah SAW bersabda: "Barangsiapa menahan diri dari memakan daging saudaranya dalam Gibah, maka menjadi kewajiban Allah untuk membebaskannya dari api neraka." (HR. Ahmad 26.328)

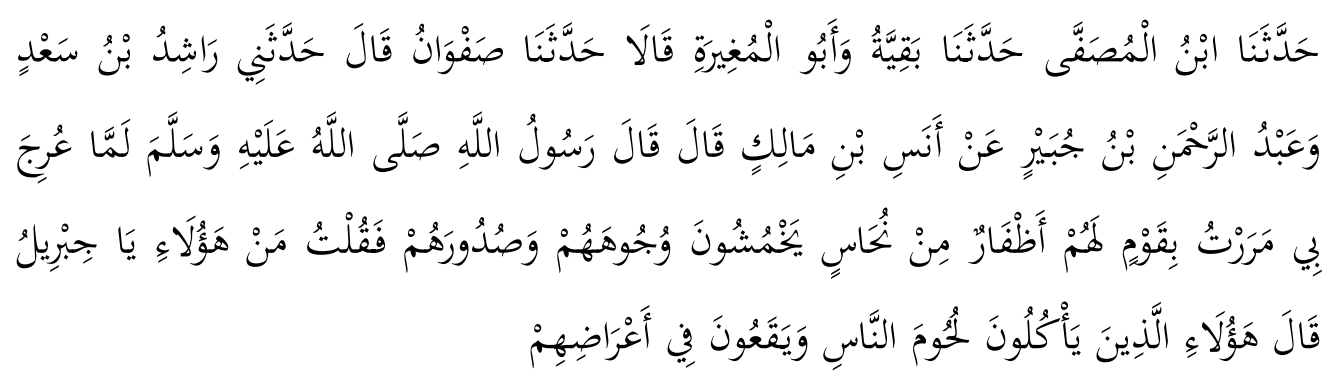

${ }^{27}$ Hamka, Tafsir Al Az̧har (Surabaya: Pustaka Islam, 1982), 26, 242-43.

${ }^{28}$ Yusuf Qardhawi, Bagaimana Memahami Hadis Nabi SAW, trans. Muhammad al-Baqir (Bandung: Karisma, 1994), 106. 
Telah menceritakan kepada kami Ibnu al-Mushaffa berkata, telah menceritakan kepada kami Baqiyyah dan Abu al-Mughirah keduanya berkata: telah menceritakan kepada kami Shafwan ia berkata; telah menceritakan kepadaku Rasyid bin Sa'd dan 'Abdurrabman bin Jubair dari Anas bin Malik ia berkata, "Rasulullab SAW bersabda: "Ketika aku dinaikekan ke langit (dimi'rajkan), aku melewati suatu kaum yang kuku mereka terbuat dari tembaga, kuku itu mereka gunakan untuk mencakar muka dan dada mereka. Aku lalu bertanya, "Wahai Jibril, siapa mereka itu?'Jibril menjawab, "Mereka itu adalah orangorang yang memakan daging manusia (gibah) dan merusak kehormatan mereka." (HR.Abu Dand 4235).

Melalui dua hadis diatas, gibah digambarkan sebagai perbuatan buruk yang harus dihindari. Pada hadis yang diriwayatkan Imam Ahmad dikatakan bahwa pembebasan dari neraka bagi orang yang menahan atau menahan gibah, sedangkan pada hadis yang diriwayatkan oleh Abu Daud berisi tentang siksaan dan perumpamaan bagi orang yang melakukan gibah dengan mencakar muka dan dada menggunakan kuku yang terbuat dari tembaga.

Pada umumnya, hadis yang berbicara tentang gibah lahir dalam konteks yang melarang perbuatan tersebut. Hal ini merupakan sebuah kewajaran lantaran gibah diartikan sebagai perbincangan tentang keburukan seseorang tidak secara langsung kepadanya. Akan tetapi, tidak semua aspek gibah merupakan hal yang terlarang karena terdapat beberapa sisi pembolehan terhadap gibah. Sebagai contoh, jika semua gibah merupakan terlarang, tentu tidak akan pernah dijumpai proses peradilan kasus KDRT karena pihak pelapor tentu akan membicarakan tentang keburukan-keburukan pelaku. Tidak hanya itu, kebiasaan untuk mengkritisi kepribadian seseorang juga diperlukan dalam dunia keislaman dengan adanya jarb wa al-Ta'dil pada kajian sanad hadis. Meskipun demikian, ada batasan-batasan tertentu yang melandasi diperbolehkannya melakukan gibah. Sedikit contoh tersebut setidaknya menunjukkan bahwa meskipun banyak dipandang sebagai sesuatu yang negatif, gibah memiliki sisi-sisi positif yang juga diperbolehkan.

\section{Analisis Kebahasaan}

Al-Gibah secara bahasa merupakan "min al ightiyab" diartikan sebagai yang tidak tampak. ${ }^{29} \mathrm{Gibah}$ juga dapat berarti umpatan, fitnah dan gunjingan. ${ }^{30}$ Gibah dalam bahasa Indonesia berarti perkataan yang memburuk-burukkan

${ }^{29}$ Ibnu Manzhur, Lisan Al-'Arab (Beirut: Dar al-Kutub al-Ilmiyah, 2009), 656.

${ }^{30} \mathrm{Ahmad}$ Warson Munawir, Al-Munawir: Kamus Arab-Indonesia (Jakarta: Pustaka Progresif, 1984), 1025. 
orang lain. ${ }^{31}$ Gibah dapat pula diartikan penggunjingan yang diidentikan dengan kata gosip, yaitu cerita negatif tentang seseorang. ${ }^{32}$ Dengan demikian, gibah dapat dipahami mempunyai arti kurang lebih sama dengan kata umpatan, penggunjingan dan gosip.

Menurut Imam Ghazali, gibah secara istilah berarti tidak hanya melakukan pengungkapan aib seseorang secara lisan, melainkan termasuk pula pengungkapan melalui perbuatan, seperti melalui isyarat tangan, mata, tulisan, dan sebagainya yang dapat dimengerti maksudnya. ${ }^{33} \mathrm{Di}$ antara aib tersebut adalah kekurangan seseorang pada tubuh, keturunan, akhlak, perbuatan, ucapan, agama, pakaian, tempat tinggal,kendaraan, dan lain sebagainya. ${ }^{34}$

Selanjutnya, kata (bahattahu) berasal dari "bahita-yabhatu-babtan" yang artinya tercengang dan diam dalam kebingungan. Sedangkan jika perubahannya

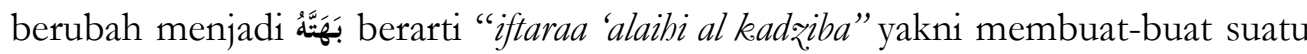
kebohongan. ${ }^{35}$ Maka dapat diketahui bahwa makna kata tersebut adalah membuat-buat suatu kebohongan yang berarti suatu hal yang tidak terjadi tetapi seseorang mengatakan bahwa itu terjadi. Ditambah lagi, jika dikaitkan dengan alQur'an, kata tersebut selalu mengarah pada hal yang berarti negatif dan disertai dengan ancaman, baik itu berupa dosa maupun ancaman dalam bentuk lain. ${ }^{36}$

Pada hadis diatas dikatakan "Apabila benar apa yang kamu bicarakan itu ada padanya, maka berarti kamu telah menggunjingnya (gibah). Dan apabila yang kamu bicarakan itu tidak ada padanya, maka berarti kamu telah membuat-buat kebohongan terhadapnya (bahattahu). Dari sini dapat disimpulkan bahwa apabila yang dikatakan sesorang itu benar maka itu adalah gibah. Sebaliknya, jika itu adalah salah/kebohongan, maka itu tergolong perbuatan yang buruk (fitnah) yang sangat harus dihindari.

\section{Pemaknaan dan Kontekstualisasi Hadis Tentang Gibah}

Kamus Besar Bahasa Indonesia mendefiniskan gibah adalah obrolan tentang orang-orang lain atau cerita-cerita negatif tentang seseorang. ${ }^{37}$ Gosip

31 WJS Poerwadarminta, Kamus Umum Bahasa Indonesia Jakarta: (Jakarta: PN. Balai Pustaka, 1985), 1125..

32 Ibid., 328.

${ }^{33} \mathrm{Abu}$ Hamid Muhammad bin Muhammad al-Ghazali, Ibya' Ulum Al-Dïn (Beirut: Dar alFikr, 1991), 154.

34 Ibid., 152-53..

35 Munawir, Al-Munawir: Kamus Arab-Indonesia, 112.

${ }^{36}$ Munzir, "Gosip Dalam Pandangan Hadis: Suatu Kajian Tematik," 93.

${ }^{37}$ Badudu and Sutan Mohammad Zain, Kamus Umum Bahasa Indonesia (Jakarta: Pustaka Sinar Harapan, 1994), 469. 
juga sering diidentikkan dengan istilah rumor dan isu yang merupakan suatu berita yang menyebar tanpa berlandaskan pada fakta yang belum atau tidak melalui sebuah klarifikasi (tabayyun). Maka, gosip merupakan sesuatu yang masih abu-abu karena bisa saja benar, namun bisa pula salah. Gosip, isu, dan rumor, ketiganya memiliki pengertian yang identik yakni informasi yang mengandung dua kemungkinan antara benar dan salah, atau dengan kata lain adalah asalusulnya tidak jelas dan diragukan kebenarannya.

Gosip tidak bisa disamakan dengan berita karena berita adalah informasi yang sudah diyakini kebenarannya melaui fakta, data, ataupun konfirmasi langsung dari para pihak (narasumber). Namun, fakta juga harus diverifikasi dulu, dipastikan kebenarannya dengan dilakukan cek-ricek atau konfirmasi.Dalam bahasa agama (Islam), verifikasi atau konfirmasi dikenal dengan istilah tabayyun. Jika tidak dilakukan sebuah tindakan verifikasi, maka sebuah berita hanya akan menjadi gosip.

Gosip dalam bahasa Arab disebut sebagai gibah . Mengenai hal ini, nabi menjelaskan definisi gibah dalam sebuah hadis riwayat Muslim sebagaimana disebutkan sebelumnya. Dari hadis tersebut, dapat ditarik kesimpulan bahwa gosip dalam perspektif penjelasan nabi adalah menceritakan tentang keburukan seseorang pada orang lain yang benar-benar ada (sesuai kenyataan) pada orang tersebut. Sedangkan menceritakan tentang keburukan seseorang yang tidak sesuai merupakan sebuah kebohongan.

Sebuah sensasi berupa kebohongan ataupun gimmick, saat ini menjadi suatu tontonan yang menarik bagi masyarakat. Hal ini terlihat dari maraknya tayangan gosip dan berbagai reality show yang lebih condong kepada ceritacerita buruk terhadap seseorang. ${ }^{38}$ Ditambah lagi, sudah menjadi watak asli para ibu-ibu (secara umum) untuk bergosip ketika berada dalam satu perkumpulan tertentu. Meskipun tidak dapat dikatakan bahwa semua lapisan masyarakat menyukai dan melakukan perilaku bergosip, perbuatan massif dari bergosip ini seolah sudah menjadi kewajaran di kalangan masyarakat. Untuk membatasi hal ini, perlu dipahami bahwa ada sisi-sisi dari gosip yang memang diperbolehkan dan dilarang dalam Islam.

\section{Diperbolehkan Bergosip}

Dalam beberapa kondisi tertentu, gosip mampu menjadi perekat sosial dan tidak selalu mengandung arti negatif. Bergosip dapat difungsikan sebagai penghubung informasi ataupun melakukan klarifikasi dari pihak-pihak terkait. ${ }^{39}$

\footnotetext{
38 Ilyas, "Ghibah Perspektif Sunnah," 157.

${ }^{39}$ Eckhaus and Ben Hador, “To Gossip or Not to Gossip,” 274.
} 
Hukum gosip/gibah terbagi menjadi haram, wajib, dan boleh. Disebutkan dalam syarah Riyadhus Shalibin mengenai beberapa jenis gibah yang diperbolehkan, antara lain:

Pertama, al-Tazallum (orang yang terzalimi). Orang yang sedang mendapat perlakuan zalim diperbolehkan menyebutkan atau mengungkapan kezalimankezaliman seseorang terhadap dirinya. Akan tetapi, penyampaian ini hanya bersifat pengaduan kepada orang atau instansi yang memiliki kapasitas untuk melenyapkan kezaliman. Sebagai contoh, seorang boleh menceritakan tindakan pengeroyokan dan kekerasan terhadapnya melalui lembaga kepolisian dan pengadilan untuk mendapatkan sebuah keadilan. Pembolehan gibah terhadap orang yang berbuat kerusakan ini berfungsi sebagai peringatan agar tidak terperdaya dengan penampilan lahiriyah mereka.

Kedua, Isti'anah (meminta pertolongan). Seperti halnya al-tazallum, pembolehan ini diarahkan untuk merubah atau menghilangkan kemunkaran dan mengembalikannya ke jalan yang benar. Contoh kasus terkait hal ini adalah melaporkan sebuah kejadian kepada orang yang diharapkan mampu menghilangkan (polisi atau aparat lainnya) bahwa terdapat sebuah kemungkaran disana, lalu kemungkaran tersebut akan ditindak oleh pihak yang berwenang.

Ketiga, al-Istifta' atau meminta fatwa dan nasihat. Perbuatan ini dapat dilakukan kepada mufti (pemberi fatwa) semisal "Saya telah dizalimi oleh fulan, apakah hal itu pantas baginya, dan apa yang harus saya lakukan?”. Permintaan fatwa dan nasihat harus disampaikan kepada pihak tertentu dan tidak untuk disebarluaskan melalui media sosial untuk menjatuhkan pihak yang dianggap bersalah.

Keempat, at-tahdzir li al-muslimin (memperingatkan orang-orang Islam) dari perbuatan buruk dan memberi nasihat pada mereka. Umat Islam sepakat bahwa perbuatan ini boleh dilakukan dan dalam kondisi tertentu bisa menjadi sebuah kewajiban karena kebutuhan.

Kelima, menyebutkan tentang orang yang menampakkan kefasikan dan perilaku maksiatnya. Perilaku semisal menampakkan diri saat minum miras, menggunakan narkoba, berpacaran di depan umum, bermain judi, dan sebagainya boleh disebutkan. Boleh disebutkan aibnya tanpa menyebut aib yang lain. Hal ini dimaksudkan untuk mengajarkan kepada masyarakat umum bahwa yang demikian merupakan contoh perbuatan buruk. Di sisi lain, pengungkapan ini dapat menjadi pelajaran bagi pelaku untuk tidak melakukan perbuatannya kembali setelah merasa malu bahwa apa yang diperbuat diketahui banyak orang.

Keenam, memberi julukan tertentu pada seseorang supaya lebih mengenalnya. Hal ini berubah menjadi haram jika dengan maksud untuk 
merendahkan. Seandainya memungkinkan untuk dipanggil dengan panggilan yang lain, maka hal itu lebih utama. ${ }^{40}$

\section{Diharamkan Bergosip}

Jika dilihat dalam konteks yang marak terjadi saat ini, gosip termasuk dalam gibah karena maksud dari gosip dan gibah dalam hal ini adalah sama. Gosip merupakan qiyas dari gibah sehingga hukumnya sama dengan gibah yaitu haram. Beberapa unsur yang ada dalam gosip menunjukkan kesamaan dalam unsur yang ada dalam gibah seperti berita yang terkandung dalam gosip hanyalah kabar burung yang belum tentu kejelasannya, sedangkan sesuatu yang tidak benar adanya maka itu disebut gunjingan atau gosip. Orang yang digunjingkan atau digosipkan mereka tidak merasa senang jika mendengar gosip karena yang diperbincangkan adalah keburukannya. Ditambah lagi, perbuatan ini berpotensi menimbulkan konflik berkepanjangan dan merusak jalinan pertemanan seseorang.

Beberapa faktor yang mendorong seseorang melakukan diantaranya adalah Kemarahan terhadap seseorang (kondisi emosional); Menyesuaikan dengan teman atau lingkungan sekitarnya (yang sedang menggunjing); Menyombongkan diri dan berpura-pura; Hasut/dengki terhadap orang yang mendapat pujian dari orang lain; Bersenda gurau dengan membanggakan diri; dan menganggap orang lain lebih rendah dari dirinya. ${ }^{41}$ Dari beberapa faktor tersebut, terdapat sebuah peneltian yang menunjukkan bahwa perbuatan gibah berpotensi menimbulkan kecemasan, stress, tekanan darah tinggi, hingga halusinasi. ${ }^{42}$

Dari beberapa sebab tersebut, gibah dapat dilakukan dalam kesadaran ataupun tidak. Namun, semuanya kembali pada dasar hukum awal menggunjing atau menggosip yang haram. Dikarenakan gibah bisa saja terjadi secara sadar dan tidak sadar, maka untuk menebus dosanya dapat dilakukan dengan penyesalan yang ditunjukkan dengan meminta maaf kepada orang yang digunjingkan. Hal demikian pernah dikatakan oleh Atha' Ibn Rabbah bahwa untuk tobat dari dosa menggunjing adalah dengan datang kepada orang yang digunjingkan dengan 668.

${ }^{40}$ Imam Nawawi, Syarah Dan Terjemah Riyadhus Shalibin (Jakarta: Al-I'tishom, 2006), 2,

41 M. Jamaluddin bin Muhammad Said al-Qasimi, Mau'idzotul Mu'minin (Surabaya: Imaratullah, n.d.), 202-3.

42 Penelitian ini mengacu baca referensi buku-buku kesehatan kardiovaskular dan mental, dengan metode dokumenter untuk mencari dampak gibah bagi kesehatan jantung. Selengkapnya lihat Nelly, "Kajian Buruk Sangka Dan Gibah Bagi Kesehatan Tubuh Manusia (Telaah Konsep Getaran Dan Gelombang)," 144. 
mengatakan padanya atas kedustaan atau kedzaliman yang dilakukannya terhadap orang tersebut. Jika ia berkehendak membalasnya maka harus diterimanya, dan jika ia tidak berkehendak membalasnya, maka minta maaflah kepadanya. ${ }^{43}$

Perkataan Atha' Ibn Rabbah tersebut menunjukkan bahwa seseorang harus bertanggung jawab atas segala apapun yang telah dilakukannya. Apabila ia termasuk orang yang bertanggung jawab, maka sudah seharusnya tidak membicarakan kejelekan orang lain dibelakangnya melainkan membicarakannya didepan (secara langsung) supaya menjadi koreksi bagi orang tersebut. Kemudian sikap yang baik bagi orang yang digunjingkan adalah tidak membalas kejelakan orang lain dengan kejelekan melainkan dibalas dengan kebaikan yaitu dengan memaafkannya bahkan mendoakannya, karena kejelekan tidak harus dibalas dengan kejelekan.

\section{Kesimpulan}

Hadis Muslim 2589 merupakan hadis yang shahih dari sisi sanad dan matannya sehingga dapat digunakan sebagai dalil dalam menghukumi perbuatan gosip/gibah. Selanjutnya, hadis-hadis yang berkaitan dengan gibah, tidak menjelaskan secara pasti terkait pembolehan atau pelarangan perbuatan ini. Adapun hukum dasar dari menggunjing adalah haram baik dilakukan secara sadar atau tidak. Namun, ada beberapa pengecualian dengan diperbolehkannya gibah melalui pertimbangan syarat tertentu, yakni: Orang yang terzalimi; Meminta pertolongan; Meminta fatwa dan nasihat; Memperingatkan orangorang Islam dari perbuatan buruk; Menyebutkan tentang orang yang menampakkan kefasikan dan perilaku maksiatnya; serta Memberi julukan tertentu pada seseorang supaya lebih mengenalnya. Dalam konteks kehidupan masa kini, gosip boleh dilakukan selama memenuhi unsur-unsur yang diperbolehkan tersebut. Sebaliknya, jika gosip ini dilakukan diluar ketentuan tersebut, perilaku gosip ini hanya akan menimbulkan dampak yang negatif. Dampak negatif tidak hanya terhadap orang lain, melainkan juga dirinya sendiri. Secara luas, gosip akan menimbulkan permusuhan, konflik, dan pencemaran nama baik. Sementara, bagi seseorang yang sering bergosip, hal ini berpotensi berdampak pada kesehatan mental yang dapat memuncak sampai tingkat stress dan gangguan jiwa.

\section{Bibliografi}

Abu Dawud, Imam. Sunan Abu Dawnd. Beirut: Maktab ad-Dirasat wa al-Buhuts fi Dar al-Fikr, n.d.

${ }^{43}$ Habib Umar bin Hafizh, Amal Pemusnah Kebaikan (Jakarta: Noura Books, 2013), 125. 
Al-Naisabury, Muslim ibn Hujjaj Al-Qusyri. Shabih Muslim. Beirut: Dar Ihya' alKutub al-'Arabiyah, n.d.

'Asqalani, Syihab al-Din Abu al-Fadhl Ahmad ibn Hajar al-. Tabrib Al-Tahzib. Beirut: al-Turas al-'Arabi, 1993.

Badudu, and Sutan Mohammad Zain. Kamus Umum Bahasa Indonesia. Jakarta: Pustaka Sinar Harapan, 1994.

Bukhari, Imam. Shahih Al-Bukhari. Riyadh: Dar 'Alam al-Kutub, 1996.

Darimi, Abdullah ibn Abdul Rahman ad-. Sunan Ad-Darimi. Saudi Arabia: Dar al-Mughni li an-Nashr wa al-Tauzi', 2000.

Eckhaus, Eyal, and Batia Ben Hador. "To Gossip or Not to Gossip: Reactions to a Perceived Request to Gossip - A Qualitative Study." Trames. Journal of the Humanities and Social Sciences 22 (September 20, 2018): 273. doi:10.3176/tr.2018.3.04.

Ghazali, Abu Hamid Muhammad bin Muhammad al-. Ibya' Ulum Al-Dïn. Beirut: Dar al-Fikr, 1991.

Hamka. Tafsir Al Az̧ar. Surabaya: Pustaka Islam, 1982.

Ilyas, Musyfikah. "Ghibah Perspektif Sunnah." Jurnal Al-Qadau: Peradilan Dan Hukum Keluarga Islam 5, no. 1 (July 3, 2018): 141-59. doi:10.24252/alqadau.v5i1.5677.

Khathib, Muhammad 'Ajaj al-. Usbul Al-Hadis: Ulumubu Wa Musthala'ubu. Beirut: Dar al-Fikr, 2011.

Manzhur, Ibnu. Lisan Al-'Arab. Beirut: Dar al-Kutub al-Ilmiyah, 2009.

Munawir, Ahmad Warson. Al-Munawir: Kamus Arab-Indonesia. Jakarta: Pustaka Progresif, 1984.

Munzir, Muhammad. "Gosip Dalam Pandangan Hadis: Suatu Kajian Tematik." Fakultas Ushuluddin UIN Alauddin, 2011.

Najwah, Nurun. Ilmu Ma'anil Hadis, Metode Pemahaman Hadis Nabi: Teori Dan Aplikasi. Yogyakarta: Penerbit Cahaya Pustaka, 2008.

Nawawi, Imam. Syarah Dan Terjemah Riyadhus Shalibin. Jakarta: Al-I'tishom, 2006.

Nelly, Azizah. "Kajian Buruk Sangka Dan Gibah Bagi Kesehatan Tubuh Manusia (Telaah Konsep Getaran Dan Gelombang)." presented at the Proseding Seminar Nasional Pendidikan Fisika, FITK UNSIQ, February 2018. 
70 | AL QUDS : Jurnal Studi Alquran dan Hadis vol. 3, no 1, 2019

Poerwadarminta, WJS. Kamus Umum Bahasa Indonesia Jakarta: Jakarta: PN. Balai Pustaka, 1985.

Qardhawi, Yusuf. Bagaimana Memahami Hadis Nabi SAW. Translated by Muhammad al-Baqir. Bandung: Karisma, 1994.

Qasimi, M. Jamaluddin bin Muhammad Said al-. Mau'idzotul Mu'minin. Surabaya: Imaratullah, n.d.

Shiddieqi, TM Hasbi as-. Sejarah Pengantar Ilmu Hadis. Semarang: Pustaka Rizki Putera, 1999.

Suryadi. "Metode Pemahaman Hadis Nabi (Telaah Atas Pemikiran Muhammad Al-Ghazali Dan Yusuf Al-Qardhawi)." Program Pascasarjana UIN Sunan Kalijaga, 2004.

Turmudzi, Abu 'Isa Muhammad ibn 'Isa ibn Saurah al-. Sunan At-Turmudzi. Beirut: Dar al-Fikr, 1994.

Umar bin Hafizh, Habib. Amal Pemusnab Kebaikan. Jakarta: Noura Books, 2013.

Yusuf, Yusuf bin Abdurrahman. Tahdribul Kamal Fi Al-Asma' Al-Rijal. Beirut: Muassasah al-Risalah, 1980. 